\title{
Promoting Learning-Purpose Communication Cases in Development of FL Specialism Communicative Competencies in EL Teacher Students
}

\author{
Anna I. Nabok \\ Academy of the State Penitentiary Service, Chernihiv, Ukraine \\ https://orcid.org/0000-0002-3696-9505 \\ Oleh S. Komar \\ Pavlo Tychyna Uman State Pedagogical University, Uman, Ukraine \\ https://orcid.org/0000-0001-8071-3905 \\ Oksana V. Yasinska
}

Lesya Ukrainka Eastern European National University, Lutsk, Ukraine https://orcid.org/0000-0002-6902-6079

Oksana M. Radavska

Lesya Ukrainka Eastern European National University, Lutsk, Ukraine https://orcid.org/0000-0002-9656-5246

Nataliia M. Slipachuk

Kamianets-Podilskyi National Ivan Ohiienko University, Kamianets-Podilskyi, Ukraine https://orcid.org/0000-0001-6504-3827

\begin{abstract}
The purpose of the study was to identify how promoting learning-purpose communication cases impacts students' communication competencies, and how this instructional model is perceived by the sampled students. 163 (119 students and 44 lecturers) from the Borys Grinchenko Kyiv University and Drahomanov National Pedagogical University were the participants used in this study. The study integrated quantitative and qualitative methods for data collection. The instruments for the study were: the ESP test, the originally designed baseline study questionnaire, teacher and studentpeer observation checklists, the Mental Speed Test, the originally designed self-reflection scale, and focussed group interview. The latter was administered to identify the perception of this instructional model by both students and teachers. The study found that the instructional model positively influences students' specialism purpose foreign language communicative competencies mainly in spoken production and spoken interaction, information processing speed, and selfreflection abilities. The results of the baseline study survey indicated that both teachers and students associated the concept of communicative
\end{abstract}


competence and focused their efforts on teaching/learning grammar, vocabulary, and pronunciation in the ESP course. The results also revealed the feasibility of the instructional model used in the study. The interviewed students' judgments of the course delivery model were also complimentary, wherein the majority of the respondents appreciated the ESP classes based on promoting learning-purpose communication cases.

Keywords: Higher education; pre-service teachers; learning-purpose communication cases; foreign language communicative

\section{Introduction}

Developing of the specialism purposes foreign language communicative competencies in the ESP (English for Specific Purposes) context among foreign language students and stressing its role among teachers is a challenging and multi-dimensional process that combines many contexts, influences, and approaches to help students achieve foreign language proficiency (Whyte, 2019). Different methods, strategies, and approaches are used to instruct communicative competencies namely: task-based instruction, the problemsolving approach, the context-based approach, Data-Driven Learning (DDL) approach, simulations, role-plays, project-based teaching, inquiry-promoting teaching strategy, and case-studies (Anthony, 2018; Shernazarova, 2019; Wozniak, 2017). Specifically, Roell (2019) emphasises on the benefits of casestudies in developing foreign language communication skills as these are useful and aimed at engaging students in situation-based spoken interactions. More than that, promoting learning-purpose communication cases (PLCCs) seems to be an integrated instructional design model that uses all methods mentioned, and that has a greater potential in training the specialism purposes foreign language communicative competencies. The reason for this is that PLCCs are flexible in updating content, structure, and instruction methods. Besides, PLCCs establish cross-disciplinary connections, illustrate the cause-effect relationship, influence students' communicative behaviours, and they are based on the trueto-life situations that assist learners to use of the authentic (not memorised) language. However, the overall ESP teaching methodology is still disintegrated, as it relies on training skills using the methods, strategies and approaches separately (Deyrich \& Stunnel, 2014).

\section{Literature Review}

The ways of communicative competence development are discussed in the scientific literature based on the perspective of reliance on their intentions and experiences which are difficult to specify and categorise (Alami, 2014).These intentions and experiences can be of social, occupational, educational or personal nature and those intentions and experiences should be influenced comprehensively through the 'learner-friendly' context (Council of Europe, 2001).The use of communication scenarios in ESP teaching is found efficient in engaging students in spoken contextualised interaction (McFarlane, 2015). The instructors can benefit from them in being effective pedagogical tools that combine learning outcomes with teaching objectives (Luptakova \& Selesova, 2016). Accordingly, communicative competence covers three key competencies 
namely: linguistic competence (grammar, vocabulary, and pronunciation), sociolinguistic competence (community values, rules, and culture), and pragmatic competence (application of the above components) (Abdulrahman \& Ayyash, 2019). In the current study, the essence of communicative competence is interpreted as an integrated account of linguistic, sociolinguistic, and pragmatic knowledge, skills, and personal traits that are applied in the context of the students' professional field. This notion aligns with Sato (2013), Dubow and Gundermann (2017), and Kolodii (2019) who emphasise the situational nature and purpose of the communicative competence. With regard to the above stated, promoting communicative competence in the ESP training is important from the instructional perspective, and therefore the present paper aims to:

1- Identify how learning-purpose communication cases influence students' communication competencies; and

2) Learn about students' perceptions as to this instructional model.

Based on the above objectives, the researchers hypothesise that:

$\mathrm{H}_{0}$ : There is no dependence of the improvement of students' communication competencies on the participation of the sampled students in the communication cases-based ESP course.

$\mathrm{H}_{1}$ : There is a dependence of the improvement of students' communication competencies on the participation of the sampled students in the communication cases-based ESP course.

\section{Methodology}

\subsection{Research Design}

The research relies on the pretest-posttest quasi-experimental design because it is found more advantageous in terms of ensuring the validity of the results (Price, 2017). The Study took place on November 2019 and lasted to the end of September 2020. It was organised as a sequence of four phases: baseline study, a pre-intervention, while-intervention, and post-intervention phases (see Figure 1). To begin with, the purpose of the baseline study was to identify how the students and teachers understand the concept of "communicative competence" and what competencies it covers. A pre-intervention phase was dedicated to designing the cases, reshaping the ESP course syllabus, sampling, and pretreatment measurements. It was also designed to identify the sample homogeneity, data collection tools and evaluation of their credibility and eligibility, and a research plan. In the while-intervention phase, however, the intervention was administered through the delivery of promoting learningpurpose communication cases, and in the post-treatment phase, the repeated measurements are administered to collect the intended data. These were followed by the focus group interview, and data were processed and recommendations were produced as well. 


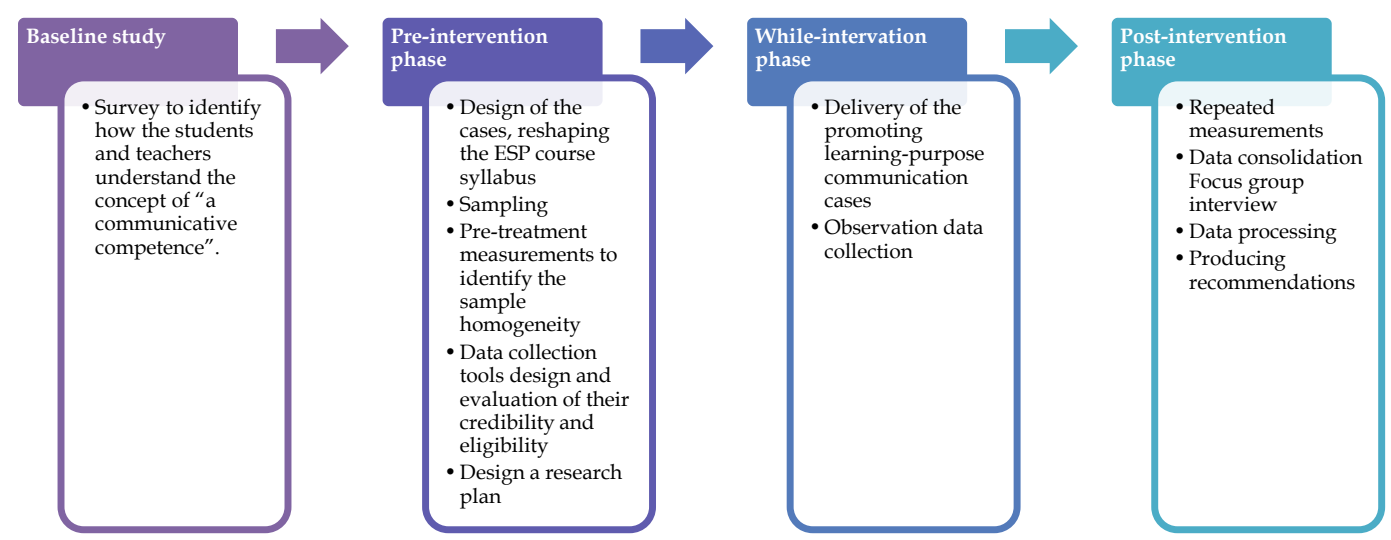

Figure 1: The research pretest-posttest quasi-experimental design of a combination design type

\subsection{Description of the Intervention}

The PLCCs were designed as a structured combination of six interconnected components, namely: a concept introducing unit which is inquiry perspectivedriven, a reflective component, a consolidation component, an information inquiry-stimulating component, a skills training unit, and a teacher guide (see Figure 2). The typical flow of the phases was as follows:

1) Introduction of the concept (see, for instance, Lesson plan 3 which is accessed via the link: https://drive.google.com/file/d/19Xyq3jsxEsWXwzp8v2U9b5E4oEJdF2E1/vie $\mathrm{w}$ ? usp=sharin ;

2) Case-studies (see some examples via the link:

https://www.eria.org/publications/economic-consequences-of-globalisationcase-study-of-thailand/ (ERIA, 2019);

2)http://ekmair.ukma.edu.ua/bitstream/handle/123456789/15748/ Abakumov a_Economic_growth_globalization_and_income_inequality.pdf?sequence $=1 \&$ is Allowed $=y$ (Abakumova \& Primierova, 2018);

3) Progress self-check: the example of this can be accessed via the link: https://drive.google.com/file/d/1r7kW7Qo3iwN1_JsHsvaEEALr0gn9pQ0c/vi ew? usp=sharin;

4) Assignment to write a solution to the problem essay or holding a debate (discussion);

5) Research assignments followed by writing a report or delivering a presentation or participating in the discussion;

6) "mistakes-to-be-corrected" drills or student-tailored skills training assignments. 


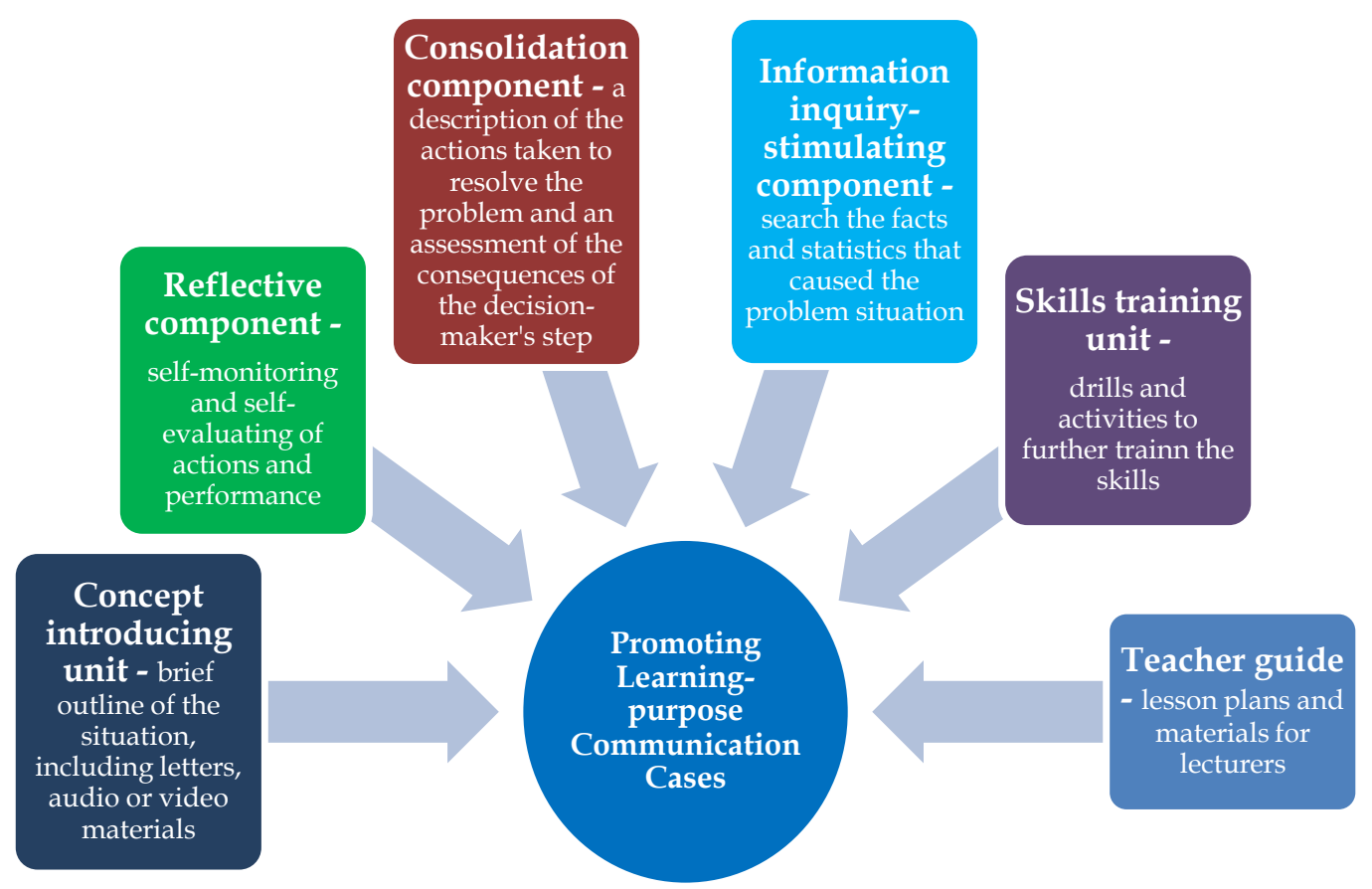

Figure 2: Structure of the promoting learning-purpose communication cases

\subsection{Sampling}

The undergraduate students from BorysGrinchenko Kyiv University and Drahomanov National Pedagogical University were the population for the study. Two sampling methods were employed at different phases of the study. First, the random sampling was utilised to select 163 respondents (119 students and 44 lecturers) for the baseline study survey and 11 students of the experimental group (EG) for the focus group interview. The convenience sampling method was used to form the EG and the control group (CG). Both groups were meant to be mutually homogeneous since they were subject to obtain a degree in the same specialism (Levy \& Lemeshow, 2011). Additionally, the Mean grades obtained from the ESP test was approximately similar (73\%, ECTS) which indicated that students were homogeneous and the sample was reliable for this study.

The EG group consisted of 24 students (6 males aged 20-21 and 18 females aged 20-21) majoring in English language teaching and seeking a Bachelor's degree at BorysGrinchenko Kyiv University, Ukraine. Whereas, the CG included 22 students (8 males aged 20-21 and 14 females aged 20-21) majoring in English language teaching and seeking a Bachelor's degree at Drahomanov National Pedagogical University, Ukraine.

\subsection{Research Methods and Data Collection Instruments}

Both quantitative and qualitative data methods were used in this study. Data on specialism purpose foreign language communicative competencies including: spoken production and spoken interaction, information processing speed, and self-reflection abilities were actually measured by means of pretest-posttest. The ESP test was also used to identify students' level on the English Language before and after the treatment. Several statistical tools were used to collect data, 
namely: the originally designed baseline study questionnaire (See Appendix A), teacher and student-peer observation checklists to assess the students' communication fluency (See Appendix B), the Mental Speed Test (MST) (Version 1), which can be accessed via the link: https://www.psychologytoday.com/us/tests/iq/mental-speed-test-version-1, to measure the students' information processing speed and the originally designed self-reflection scale to measure the students' self-reflection abilities (See Appendix C). A focus group interview was administered to identify students' and teachers' perceptions towards the instructional model (See Appendix D). The following sub-sections explain each research instrument and the methods the investigators used to validate the gathered data.

3.4.1. The ESP Test. The test comprised of three sections which are: reading comprehension, structure, and compositional analysis, whereas the speaking skills were tested orally. Each section covered 20 questions (a total of 60 questions). The test was piloted and DIF and DTF methods were used to analyse its validity and reliability. The questions that show DIF were identified using the Lord's Chi-square DIF method giving a value 0.01 ( $\alpha$ - significance level), and the threshold which was 8.932. The impacts of DIF items on the test scores were analysed using the Mantel-Haenszel/Liu-Agresti DTF method. The items with the values drawn from the DTF that were higher than 0.14 were considered sufficient for the final ESP test version.

3.4.2. The Baseline Study Questionnaire. It was a structured survey questionnaire consisting of nine items to rate using 5-point Likert Scale. It covered linguistic and extra-linguistic dimensions of communicative competence such as overall fluency and interaction (strategic) skills along with linguistic and lingua-professional skills and abilities. The content of the questionnaire was validated by the team members.

\subsubsection{The Teacher and Student-peer Observation Checklist on Using English as a}

Medium of Communication. The checklist relies on ten questions using a fivepoint Likert performance rating scale. The teachers rated their students' spoken production and spoken interaction in the classes using the values that ranged from $1=$ Bad performance to $5=$ Excellent performance. To validate the checklist, it was reviewed by a panel of three experts, in which the first expert was a CELTA-certified English Language Teacher, the second expert was a Ph.D. holder on Pedagogic, and the third expert had a background in Statistics. Every expert first assessed the clarity, significance, and concreteness of the questions applying a four-point-based rating scale with the values from $1=$ 'not clear' or 'not concrete' or 'not substantial' up to 4 = 'totally clear' or 'absolutely concrete' or 'very substantial'. The content validity index (CVI) of each item was then calculated as recommended by Yusoff (2019). When the CVI was higher than $2.90(72.5 \%)$, it is therefore considered adequate for the item to be included in the checklist. The final validation of the questionnaire was performed during the panel meeting which was followed by the coding procedure as recommended by Veal and Darcy (2017). 
3.4.4. The Mental Speed Test. The MST is a 5-minute test that can be accessed via the link: https://www.psychologytoday.com/us/tests/iq/mental-speed-testversion-1/. It assesses the test siter's mental speed in terms of information processing and decision-making. The test consists of 41 questions that use pairs of words vs images, mathematical equations, or number sequences. The test uses a binary scale for the respondent to decide whether the answer is "Correct" or "Incorrect". The test was found to be reliable by an expert in psychology with a Ph.D. degree.

3.4.5. The Self-Reflection Scale. The scale encompassed three subscales; awareness, desire, and involvement. It includes 15 items. The content of the scale was validated by the team members and the hired expert with a Ph.D in Psychology. The construct validity evaluation was performed with confirmatory factor analysis (CFA) and exploratory factor analysis (EFA).The Chi-square test $\chi^{2}$ based on the comparative fit index (CFI), goodness-of-fit index (GFI), standardised root mean square residual (SRMR) and root mean square error of approximation (RMSEA) are used to compute the fitness of the scale. The thresholds indices such as p-value of $\chi^{2}>.05$, CFI $>.95$, TLI $>.95$, RMSEA $<.08$, and SRMR $<.08$ were considered to be of satisfactory fit for this instrument, as claimed by Kline (2016). Accordingly, the above values were sufficient to decide that the scale was valid. Following that, the randomly selected students were required to complete the questionnaire twice in hope to monitor the questionnaire test-retest reliability. The internal consistency and test-retest reliability of the scale were measured by computing Cronbach's alpha coefficient. This was then followed by the calculation of the interclass correlation coefficient (ICC). The value which was more than 0.70 for Cronbach's alpha and ICC were regarded as sufficient.

3.4.6. The Focus Group Interview Questionnaire. The questionnaire consisted of 4 open-ended questions arranged step-wise as recommended by Krueger \& Casey (2015). More explicitly, it enclosed four purposeful questions: an exploring general impression question, two reflective questions for identifying positive and negative respondents' experiences, and an ending question to identify the interviewees' perceptions and encourage them to make suggestions of how to improve the intervention. Three randomly selected volunteer lecturers interview the respondents individually. One interview lasted approximately 30 minutes as the interviewees could be asked follow-up questions to clarify their ideas. The interview was recorded and then made textualised to be further analysed to specify the topics. Concurrently, the Raven's Eye software (https:// ravens-eye.net/) was utilised to categorise and code the responses. The Raven's Eye software is considered a reliable instrument to analyse qualitative data for the research purpose (Kunal, 2020).

\section{Results}

The results are presented in three main parts such as a baseline study, intervention, and focus group interview. Primarily, the data yielded from pretest and posttest measurements showed that promoting learning-purpose communication cases positively influence students' communication 
competencies, and the instructional model was hence positively perceived by the students.

\subsection{The Results of the Baseline Study Survey}

The respondents were supposed to rate each specified feature of the communicative competence (CC) using the 5-point Likert importance scale to explore the understanding of the $\mathrm{CC}$ concept by both students and lecturers (teachers). As can be seen in Figure 3, the CC concept was mainly associated among the respondents with linguistic knowledge features such as accuracy in grammar, pronunciation, and use of language (vocabulary), and the abilities to comprehend what others say. They considered the ability to interact verbally and in writing, the ability to deliver the message clearly, and abilities and skills to establish rapport, use empathy, engage in conversation, and manage time as secondary skills as to $\mathrm{CC}$. The features such as the appropriate and relevant demeanour, non-verbal behaviour, and abilities to use discourse strategies relevantly were given third priority by the respondents.

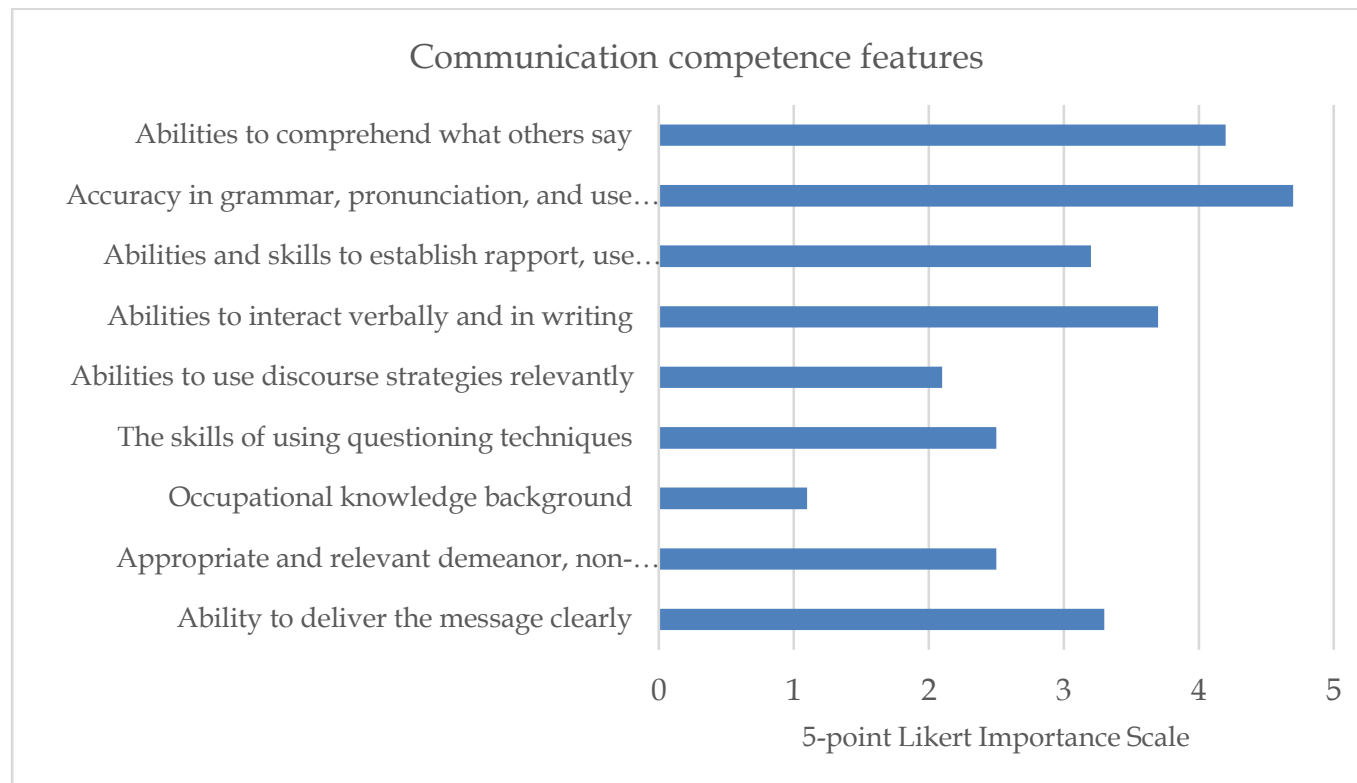

Figure 3: Distribution of respondents' judgements on the importance of the features of the communication competence

The results in Figure 3 suggested that both teachers and students focused their efforts on teaching/learning grammar, vocabulary, and pronunciation in the ESP course. The results proved the feasibility of the instructional model used in the study.

The consolidated results were obtained from the pretest-posttest measurements using teacher and student-peer observation checklists (TSOC), the Mental Speed Test (MST), and the self-reflection scale (SRC). The Paired T-Test Calculator which is accessed via lia link: https://www.statskingdom.com/160MeanT2pair.html, was used to make measurements in the EG and CG (Table 1). 
Table 1: The results drawn from a Paired sample T-test

\begin{tabular}{|c|c|c|c|c|c|c|c|c|}
\hline \multirow{2}{*}{ Group } & \multicolumn{2}{|c|}{ Mean } & \multicolumn{2}{|c|}{ SD } & \multirow{2}{*}{$\begin{array}{l}\text { Normality } \\
p-\text { value }\end{array}$} & \multirow{2}{*}{$\begin{array}{l}t \\
- \text { value }\end{array}$} & \multirow[b]{2}{*}{$d$} & \multirow{2}{*}{$\begin{array}{l}p \\
- \text { value }\end{array}$} \\
\hline & B & $\mathrm{A}$ & B & $\mathrm{A}$ & & & & \\
\hline$E G=24$ & 3.56 & 4.15 & 0.46 & 0.41 & 0.2591 & 3.5886 & 0.73 & 0.001553 \\
\hline$C G=22$ & 3.57 & 3.77 & 0.44 & 0.40 & 0.00002925 & 0.7056 & 0.15 & 0.4882 \\
\hline
\end{tabular}

Note: B-Before; A-After; d - effect size.

\subsection{Validation of the Results Obtained from a Paired Sample T-test, Using $T$ Distribution ( $D F=23$ for EG and DF=21 for CG) (two-tailed)}

The p-value equals 0.001553 for the EG and 0.7056 for the CG. It means for the EG that the chance of type1 error (rejecting a correct $\mathrm{H}_{0}$ ) is small: 0.001553 $(0.16 \%)$, and therefore the p-value supports $\mathrm{H}_{1}$. In the $\mathrm{CG}$, it indicates that the chance of type I error, rejecting a correct $\mathrm{H}_{0}$, is too high: $0.4882(48.82 \%)$. The test statistic T equals 3.5886 for the EG and 0.7056 for the CG, which is not in the 95\% region of acceptance: [-2.0687:2.0687], and the $x=0.48$ is not in the $95 \%$ region of acceptance: [-0.2786: 0.2786]. The standard deviation of the difference, $S^{\prime}$ equals 0.135 (EG) and 0.277 (CG), is used to calculate the statistics.

The observed effect size $d$ in the EG is large (0.73), while it is small in the CG (0.15). This points out that for the EG, the magnitude of the difference between the average and $\mu 0$ is large, and for the CG is small. The values imply that there was an improvement in communication competence, information processing speed, and self-reflection abilities in both EG and CG students. However, the effect size in the EG was by far higher (0.58 points) than in the CG.

\subsection{Results of the Focus Group Interview}

As for the first question, seven respondents appreciated the ESP classes based on promoting learning-purpose communication cases, while the others were neutral about them. Some of the illustrative quotes were as follows:

[...classes were engaging and interesting ... we did a lot of pair work and collaborated with other students...]

[... I felt that I improved professionally...]

[... we did a lot of tasks that we benefited from...]

Data on the second question, four respondents reported improvements in analysing the situations critically. Five students mentioned that they learned to apply self-assessment techniques, and two students answered that their English language fluency improved. One of the respondents claimed the following:

[ ... I dealt with my psychological barriers in speaking English both as a presenter and a team member...]

Concerning the third question, eight students showed dissatisfaction with the inquiry component for being quite challenging. Three students were unpleased about the reflection phase stating that self-evaluation is not their interest.

As far as the last question in the interview, six students suggested using more tailored inquiry section assignments, while five respondents proposed linking the ESP course to some specific academic discipline or course. 


\section{Discussion}

The current study was intended to identify how promoting learning-purpose communication cases impact students' communication competence and how this instructional model was perceived by the present research informants. The novelty of the study is in a specifically structured instructional design that is driven by the inquiry perspective of fostering communicative competencies within the students' professionalism context. It was found that the instructional model positively influences students' specialism purpose foreign language communicative competencies such as spoken production and spoken interaction, information processing speed, and self-reflection abilities. The results of the baseline study survey suggested that both teachers and students associated the concept of communicative competence and focused their efforts on teaching/learning grammar, vocabulary, and pronunciation in the ESP course. The results revealed the feasibility of the instructional model used in the study. The values obtained for measurements of the consolidated data yielded from the pretest-posttest measurements using teacher and student-peer observation checklists (TSOC), the Mental Speed Test (MST), and self-reflection scale (SRC) imply that there was an improvement in communication competence, information processing speed, and the self-reflection abilities in both EG and CG students.

The results obtained and concluded from this study were also supported by the responses of the interviewed students. Most of the respondents appreciated the ESP classes based on promoting learning-purpose communication cases, while a minority reported improvements in analysing the situations critically, and almost half of them mentioned that they learned to apply self-assessment techniques. Two students posited that their English language fluency improved. As far as what they have suggested is concerned, using more tailored inquiry section assignments, and linking the ESP course to some specific academic discipline or course were seen important to its flourishing implementation.

Indeed, the findings of the study align with some previous studies. More specifically, the baseline study run by the British Council Ukraine (2019) uncovered that there was a lack of consistency in the approach to ESP and EMI nationwide, ineffective teaching methodology, issues with developing the materials and assessment that lead to diversity, and overarching concern of the educational stakeholders over the quality of ESP courses. The findings of the study are consistent with the literature on effectiveness of contextualisation and localisation in learning through cases. In this light, Garin et al., (2017) concludes that the use of indigenous content is effective from the perspective of the instructor and learner. The study also goes with Andriotis's findings (2017) who advocates the idea that contextualizing can both address the students' future job context and improve teaching and learning outcomes. The results adjust to Kostenko (2020) who implies that self-assessment practices and communicative activities based on real-life contexts increase the effectiveness of the ESP course in terms of developing students 'communication competence. The study is consistent with Lavrysh (2016) who proved that peer and self-assessment accelerate students' critical thinking skills, maintained their learning motivation, 
and increases their engagement in learning. The study agrees with Roell (2019) emphasising the benefits of using case-study methodology such as exposing students to the real job. According to Bonney (2015), the case-studies rely on Bloom's taxonomy of cognitive learning and develop higher-order cognitive skills such as analysis, synthesis, and evaluation that are followed by application.

\section{Conclusion}

The study concluded that the instructional model positively influences students' specialism purpose foreign language communicative competencies such as spoken production and spoken interaction, information processing speed, and self-reflection abilities. The results of the baseline study survey suggested that both teachers and students associated the concept of communicative competence and focused their efforts on teaching/learning grammar, vocabulary, and pronunciation in the ESP course. The results stressed the feasibility of the instructional model used in the study, and improvement in communication competence, information processing speed, and self-reflection abilities in both EG and CG students were achieved. The interviewed students' judgements of the course delivery model were also complimentary. The majority of the respondents appreciated the ESP classes based on promoting learning-purpose communication cases, and some of them showed improvements in analysing the situations critically. With reference to what has been put forward by the respondents, further research should study how the tailored inquiry assignments can influence the development of the communicative competence of the students doing the ESP course. Besides, future endeavours should also investigate the issue of how the integration of the ESP course into some specific academic discipline can have an effect on the students' language skills.

\section{Acknowledgement}

We are thankful to the experts for their expertise in invalidating the instruments. We also express our gratefulness to all the sampled students and teachers for being diligent and for projecting a positive attitude.

\section{Limitations}

The limitations of this study are related to the involvement of only one institution in the experiment and the sample size.

\section{Conflicts of Interest}

The authors report no conflicts of scientific or financial interest that can be associated with the accomplishment of the present study.

\section{References}

Abakumova, J., \& Primierova, O. (2018). Economic growth, globalization, and income inequality: the case of Ukraine. In T. Kliestik (Ed.), Proceedings for the 18th International scientific conference globalization and its socio-economic consequences (pp.

http://ekmair.ukma.edu.ua/bitstream/handle/123456789/15748/Abakumova_ Economic_growth_globalization_and_income_inequality.pdf?sequence=1\&isAll owed $=\mathrm{y}$ 
Abdulrahman, N. C., \& Ayyash, E. A. S. A. (2019). Linguistic competence, communicative competence, and interactional competence. Journal of Advances in Linguistics, 10, 1600-1616. https://doi-org/10.24297/jal.v10i0.8530

Alami, S. E. A. (2014). Promoting communicative competence within EFL contexts: A UAE case study. Journal of Language Teaching and Research, 5(6), 1245-1255. https:// doi.org/10.4304/jltr.5.6.1245-1255

Andriotis, N. (2017). Contextualized learning: Teaching made highly effective. https://www.efrontlearning.com/blog/2017/06/contextualized-learningeffective-elearning.html

Anthony, L. (2018). Introducing English for specific purposes (1 ${ }^{\text {st }}$ ed.). Routledge. https://doi-org/10.4324/9781351031189

Bonney, K. M. (2015). Case study teaching method improves student performance and perceptions of learning gains. Journal of Microbiology \& Biology Education, 16(1), 21-28. https://doi.org/10.1128/jmbe.v16i1.846

Council of Europe. (2001). Common European framework of reference for languages: Learning, teaching, assessment - Companion volume. https://www.coe.int/en/web/common-european-framework-referencelanguages

Deyrich, M.-C., \& Stunnel, K. (2014). Language teacher education models: New issues and challenges. In J. D. M. Agudo (Ed.), English as a foreign language teacher education (pp. 83-105). Rodopi. https://doi.org/10.1163/9789401210485_007

Dubow, G., \& Gundermann, S. (2017). Certifying the linguistic and communicative competencies of teachers in English-medium instruction programmes. Language Learning in Higher Education, 7(2), 475-487. https://doi.org/10.1515/cercles-20170021

ERIA. (2019). Economic consequences of globalisation: Case study of Thailand. https://www.eria.org/publications/economic-consequences-of-globalisationcase-study-of-thailand/

Garin, R., Reyes, R., Domantay, G., \& Rosals, J. (2017). Contextualized and Localized teaching as a technique in teaching basic statistics. Asia Pacific Journal of Education, Arts and Sciences, 4(1), 62-67. http://apjeas.apjmr.com/wpcontent/uploads/2017/05/APJEAS-2017.4.1.2.08.pdf

Kolodii, N. V. (2019). The modification of the formation of professional linguistic competencies of future factors of social work. Innovate Pedagogy, 12(1), 106-110. https:// doi.org/10.32843/2663-6085.2019.12-1.22

Kostenko, N. (2020). Developing communicative competence in English as a second language by integrating business competencies. Scientific Issues of Vinnytsia State M. Kotsyubynskyi Pedagogical University. Section: Pedagogics and Psychology, 216(58), 109-115. https:// doi.org/10.31652/2415-7872-2019-58-109-115

Krueger, R. A., \& Casey, M. A. (2015). Focus group interviewing. In K. E. Newcomer, H. P. Hatry \& J. S. Wholey (Eds.), Handbook of practical program evaluation (pp. 506534), Jossey - Bass. https:/ / doi.org/10.1002/9781119171386.ch20

Kunal, N. (2020). New comprehensive report on qualitative data analysis software market to witness an outstanding growth during 2020-2025 with top players like Provalis Research, WebQDA, Raven's Eye, Research Ware, FOCUSSON, Audio transcription, Qiqqa, Aquad, Dovetail. https://thedailychronicle.in/news/72267/newcomprehensive-report-on-qualitative-data-analysis-software-market-to-witnessan-outstanding-growth-during-2020-2025-with-top-players-like-provalisresearch-webqda-ravens-eye-researc/

Lavrysh, Y. (2016). Peer and self-assessment at ESP classes: Case study. Advanced Education, 1, 60-68. https://doi.org/10.20535/2410-8286.85351 
Levy, P. S., \& Lemeshow, S. (2011). Two-stage cluster sampling: Clusters sampled with equal probability. In P. S. Levy \& S. Lemeshow (Eds.), Sampling of Populations: Methods and Applications (pp. 269-330). Wiley Online Library. https://doi.org/10.1002/9780470374597.ch10

Luptakova, J., \& Selesova, D. (2016). Tools for skills: Teacher training. How to use case studies. National Forest Center.

McFarlane, D. A. (2015). Guidelines for using Case studies in the teaching/learning $\begin{array}{llll}\text { process. } & \text { College } & \text { Quarterly, } & 18(1),\end{array}$ https:// files.eric.ed.gov/fulltext/EJ1070008.pdf

Price, P. C. (2017). Quasi-experimental research. In P. C. Price, R. S. Jhangiani, I-C. A. Chiang, D. C. Leighton \& C. Cuttler (Eds.), Research methods in psychology (3 ${ }^{\text {rd }}$ ed.). PB Press books.

Roell, C. (2019). Using a case study in the EFL classroom. English teaching forum. https://files.eric.ed.gov/fulltext/EJ1236098.pdf

Sato, M. (2013). Beliefs about peer interaction and peer corrective feedback: Efficacy of classroom intervention. The Modern Language Journal, 97(3), 611-633. https://doi.org/10.1111/j.1540-4781.2013.12035.x

Shernazarova, H. (2019). Developing communicative competence by implementing project based-learning in ESP classes. Philology Matters, 3, 145-153. https://doi.org/10.36078/987654373

Veal, A. J., \& Darcy, S. (Eds.). (2017). Research methods in sports studies and sport management: A practical guide (1 ${ }^{\text {st }}$ ed.). Routledge. https://doi.org/10.4324/9781315776668-12

Whyte, S. (2019). Revisiting communicative competence in the teaching and assessment of language for specific purposes. Language Education \& Assessment, 2(1), 1-19. https://doi.org/10.29140/lea.v2n1.33

Wozniak, M. (2017). ESP in CLIL degree programmes. ESP Today, 5(2), 244-265. https:// doi.org/10.18485/esptoday.2017.5.2.6

Yusoff, M. S. B. (2019). ABC of content validation and content validity index calculation. Education in Medicine Journal, 11(2), 49-54. https://doi.org/10.21315/eimj2019.11.2.6 
Appendix A: Baseline Questionnaire (Adapted from Whyte, 2019).

\begin{tabular}{|c|l|l|l|l|l|l|}
\hline$\#$ & How much do the following address the high level of & \multicolumn{5}{|c|}{$\begin{array}{l}\text { 5-point Likert } \\
\text { importance scale }\end{array}$} \\
\cline { 4 - 6 } & & & 2 & 3 & 4 & 5 \\
\hline 1 & Ability to deliver the message clearly. & & & & & \\
\hline 2 & $\begin{array}{l}\text { Appropriate and relevant demeanour, non-verbal } \\
\text { behaviour. }\end{array}$ & & & & \\
\hline 3 & Occupational knowledge background. & & & & \\
\hline 4 & The skills of using questioning techniques. & & & & & \\
\hline 5 & Abilities to use discourse strategies relevantly. & & & & \\
\hline 6 & Abilities to interact verbally and in writing. & & & & \\
\hline 7 & $\begin{array}{l}\text { Abilities and skills to establish rapport, use empathy, } \\
\text { engage in conversation, and manage time. }\end{array}$ & & & & & \\
\hline 8 & $\begin{array}{l}\text { Accuracy in grammar, pronunciation, and use of language } \\
\text { (vocabulary). }\end{array}$ & & & & & \\
\hline 9 & Abilities to comprehend what others say. & & & & \\
\hline
\end{tabular}

Note: $1=$ Unimportant; $2=$ Slightly Important; 3=Moderately Important; 4=Important; $5=$ Very Important.

Appendix B: The teacher and student-peer observation checklist on using English as a communication media

\begin{tabular}{|c|c|c|c|c|c|c|}
\hline \multirow[t]{2}{*}{ \# } & \multirow[t]{2}{*}{ Item } & \multicolumn{5}{|c|}{$\begin{array}{l}\text { 5-point Likert } \\
\text { performance } \\
\text { rating scale }\end{array}$} \\
\hline & & 1 & 2 & 3 & 4 & 5 \\
\hline 1 & The student is generally fluent and easy to follow. & & & & & \\
\hline 2 & The student uses functional language appropriately. & & & & & \\
\hline 3 & $\begin{array}{l}\text { The student uses professionalism-related terms relevantly and } \\
\text { appropriately. }\end{array}$ & & & & & \\
\hline 4 & The student uses exponents appropriately. & & & & & \\
\hline 5 & The student speaks cohesively. & & & & & \\
\hline 6 & The student speaks coherently. & & & & & \\
\hline 7 & $\begin{array}{l}\text { The student uses a "five-finger strategy" to provide } \\
\text { arguments. }\end{array}$ & & & & & \\
\hline 8 & The student uses persuasion techniques. & & & & & \\
\hline 9 & $\begin{array}{l}\text { The student shows good time management skills when } \\
\text { communicating the idea. }\end{array}$ & & & & & \\
\hline 10 & The student uses their body language confidently. & & & & & \\
\hline
\end{tabular}

Note: $1=$ Bad performance; $2=$ Below the average performance; $3=$ Average performance; $4=$ Good performance; $5=$ Excellent performance.

Appendix C: Self-Reflection Scale

\begin{tabular}{|c|c|l|}
\hline Subscale & $\#$ & \\
\hline Awareness & 1 & I am usually aware of how I express myself. \\
\cline { 2 - 4 } & 2 & I am usually aware of what feeling my words stimulate. \\
\cline { 2 - 4 } & 3 & I am usually aware of the strategy I use to influence people. \\
\cline { 2 - 4 } & 4 & $\begin{array}{l}\text { I am aware of the reasons for my behaviour in certain } \\
\text { communication situations }\end{array}$ \\
\cline { 2 - 4 } & 5 & Sometimes the way I communicate a message confuses people. \\
\cline { 2 - 4 } & 6 & Sometimes the way I communicate a message confuses me. \\
\hline
\end{tabular}




\begin{tabular}{|c|c|l|}
\hline \multirow{2}{*}{ Desire } & 7 & $\begin{array}{l}\text { I am usually aware of how my communication-related thinking } \\
\text { works. }\end{array}$ \\
\cline { 2 - 3 } & 8 & $\begin{array}{l}\text { I am usually aware of how my feelings are related to } \\
\text { communication work. }\end{array}$ \\
\cline { 2 - 3 } & 9 & $\begin{array}{l}\text { I feel it important to evaluate the way I communicate and } \\
\text { interact with others. }\end{array}$ \\
\cline { 2 - 3 } & 10 & $\begin{array}{l}\text { I am interested in evaluating the way I behave in } \\
\text { communication and interaction. }\end{array}$ \\
\cline { 2 - 3 } & 11 & $\begin{array}{l}\text { I feel it essential to provide reasoning to my every } \\
\text { communication success and failure. }\end{array}$ \\
\cline { 2 - 3 } & 12 & $\begin{array}{l}\text { I feel it essential to examine the way how I build and develop } \\
\text { my arguments. }\end{array}$ \\
\hline Involvement & 13 & I hardly dedicate time to self-analysing my thoughts. \\
\cline { 2 - 3 } & 14 & I hardly dedicate time to self-analysing my feelings. \\
\cline { 2 - 3 } & 15 & I regularly take time to do self-reflection. \\
\hline
\end{tabular}

Appendix D: Focus Group Interview Questions

1. What do you think about the ESP classes based on promoting learningpurpose communication cases?

2. How did this educational experience address your needs and expectations?

3. What caused you to feel disappointed in this educational model?

4. According to you, how this educational model can be made more effective? 